NOTICE: this is the author's version of a work that was accepted for publication in Diabetes Research and Clinical Practice. Changes resulting from the publishing process, such as peer review, editing, corrections, structural formatting, and other quality control mechanisms may not be reflected in this document. Changes may have been made to this work since it was submitted for publication. A definitive version was subsequently published in Diabetes Research and Clinical Practice, Vol. 102, No. 2 (2013).

DOI: 10.1016/j.diabres.2013.08.010 


\section{Alcohol and type 1 diabetes: patient knowledge of alcohol-induced sustained hypoglycaemia}

Sally A. Vindedzis ${ }^{1}$ MSc, Beryl Marsh ${ }^{1}$ RN, Jill L. Sherriff ${ }^{2}$ PhD, Kim G. Stanton ${ }^{1}$ MB.

Department of Endocrinology and Diabetes, Royal Perth Hospital, Perth, WA, 6001

School of Public Health, Curtin Health Innovation Research Institute, Curtin University, Bentley, WA, $6102^{2}$

Word count: 406 words (excluding references).

Funding/competing interests: None

Corresponding author: Sally Vindedzis,

Department of Endocrinology and Diabetes

Royal Perth Hospital

GPO Box X2213, Perth, Western Australia, 6001

Phone: + 6108 64775213, Fax: +610864775238

Email: sally.vindedzis@postgrad.curtin.edu.au 
In type 1 diabetes alcohol can significantly reduce blood glucose 6-8h post-consumption [1] with increased risk lasting 24h [2]. Risk is dose-related and can be reduced with judicious carbohydrate consumption and long-acting insulin reduction where necessary [1]. There are, however, few studies assessing, firstly, easily available information and secondly, patients' knowledge in this area. We accessed and assessed National Diabetes Association guidelines, as typical information retrievable from an internet search for 'alcohol and type 1 diabetes' and also assessed knowledge of alcohol and hypoglycaemia in adults with type 1 diabetes by questionnaire.

Questionnaire items assessed knowledge of the hypoglycaemic effect of alcohol, duration of hypoglycaemia post-consumption and number of standard drinks perceived to cause hypoglycaemia. Standard drink quantity was depicted for comparison. Risk reduction (dietary or insulin modification) was not addressed to minimize prejudicing assessment of knowledge of hypoglycaemic effect per se. Questionnaire readability was 7.3 on Flesch-Kincaid Grade-Level score, thus understandable by a seventh grader. It was distributed to 50 consecutive adults with type 1 diabetes $\geq 18 \mathrm{y}$ attending routine outpatient clinics; was anonymous, and consent was presumed by return to a designated sealed box.

Results: Information on alcohol and hypoglycaemia provided by 6 National Diabetes Associations [38] is shown in Table 1. All provided general information on alcohol and hypoglycaemia, eating with, and snacking after alcohol, and sustained hypoglycaemic effect, but the possible duration of hypoglycaemia varied from not specified to $16-24 \mathrm{~h}$. Only 2 guidelines provided information on reduction of long-acting insulin. Questionnaires were returned by 37 (74\%) participants, exceeding the acceptable return rate of $65 \%$ for self-completed questionnaires [9]. Diabetes duration was $16.5 \pm 11.9 \mathrm{y}$ and treatment was by basal-bolus $(83.8 \%) / \mathrm{CSII}(16.2 \%)$. The hypoglycaemic effect of alcohol was correctly identified by $88.2 \%$ of responders, but only $32.4 \%$ postulated duration of $4+\mathrm{h}$ post-consumption. Standard drink quantity perceived to lower blood glucose level was: 1-3 (50\%) and $4+(41.2 \%)$. Study limitations were small sample size (50) and the notorious difficulty of obtaining accurate information on alcohol consumption. We aimed to maximise accuracy by the proven strategy of anonymity [10] and assessment of knowledge rather than behaviour.

Conclusions: Knowledge of alcohol and hypoglycaemia was acceptable in this group, except in the important area of duration of alcohol-induced hypoglycaemia. This is congruent with accessed 
guidelines and may reflect an identified lack of consistency in information given to patients regarding alcohol-induced hypoglycaemia [2]. Additionally not all guidelines provided information on reduction of long-acting insulin, an important strategy to minimize hypoglycaemic risk.

\section{References}

1. Choudhary P, Amiel SA: Hypoglycaemia: current management and controversies. Postgrad Med J 2011;87:298-306

2. Richardson T, Weiss M, Thomas P, Kerr D: Day After the Night Before: Influence of evening alcohol on risk of hypoglycemia in patients with type 1 diabetes. Diabetes Care 2005;28:1801-1802

3. American Diabetes Association [Homepage on the Internet]. Alcohol. Virginia: American Diabetes Association. Available at: http://www.diabetes.org/food-and-fitness/food/what-can-ieat/alcohol.html. Accessed 30 July 2013.

4. Canadian Diabetes Association [Homepage on the Internet]. Alcohol and Diabetes. Canada: Canadian Diabetes Association. Available at: http://www.diabetes.ca/forprofessionals/resources/nutrition/alcohol/. Accessed 30 July 2013.

5. Diabetes Australia [Homepage on the Internet]. Alcohol and Diabetes. Canberra: Diabetes Australia. Available at: http://www.diabetesaustralia.com.au/Living-with-Diabetes/EatingWell/Alcohol/. Accessed 30 July 2013.

6. Diabetes New Zealand [Homepage on the Internet]. Hypoglycaemia. New Zealand: Diabetes New Zealand. Available at: http://www.diabetes.org.nz/living_with_diabetes/type_1 diabetes/low_blood _glucose_hypo Accessed 29 July 2013.

7. Singapore Diabetic Association [Homepage on the Internet]. Hypoglycaemia. Singapore: Singapore Diabetic Association. Available at: http://www.diabetes.org.sg/resources/0111-hypo.pdf. Accessed 30 July 2013.

8. Diabetes UK [Homepage on the Internet]. Alcohol Diabetes, Hypoglycaemia. UK: Diabetes UK. Available at: http://www.diabetes.org.uk/Guide-to-diabetes/Healthy_lifestyle/Alcohol_and_diabetes/ Accessed 30 July 2013.

9. Kelley K, Clark B, Brown V, Sitzia J: Good practice in the conduct and reporting of survey research. Int J Qual Health Care 2003;15:261-266 
10. Beck F, Peretti-Watel P: The Impact of Data Collection Methodology on the Reporting of Illicit Drug Use by Adolescents. Population-E 2002;57:571 - 592 
Table 1 Alcohol and insulin: information provided by guidelines

\begin{tabular}{|c|c|c|c|c|c|c|}
\hline \multirow[b]{2}{*}{$\begin{array}{l}\text { National } \\
\text { Association }\end{array}$} & \multicolumn{6}{|c|}{ Information provided } \\
\hline & $\begin{array}{l}\text { Potential } \\
\text { hypoglycaemic } \\
\text { effect }\end{array}$ & $\begin{array}{l}\text { Duration of } \\
\text { hypoglycaemia } \\
\text { - } \quad y / n \\
\text { - } \quad \text { time } \\
\end{array}$ & $\begin{array}{l}\text { Food } \\
\text { with } \\
\text { alcohol }\end{array}$ & $\begin{array}{l}\text { Snack } \\
\text { later }\end{array}$ & $\begin{array}{l}\text { Possible } \\
\text { insulin } \\
\text { reduction }\end{array}$ & $\begin{array}{l}\text { Recommends } \\
\text { further } \\
\text { Information }\end{array}$ \\
\hline $\begin{array}{l}\text { American } \\
\text { Diabetes } \\
\text { Association }\end{array}$ & $\mathrm{y}$ & $\begin{array}{l}\text { - } \quad \mathrm{y} \\
\text { - up to } 24 \mathrm{~h}\end{array}$ & $\mathrm{y}$ & $\mathrm{y}$ & $\mathrm{n}$ & $\mathrm{y}$ \\
\hline $\begin{array}{l}\text { Canadian } \\
\text { Diabetes } \\
\text { Association }\end{array}$ & $\mathrm{y}$ & $\begin{array}{l}\text { - } \quad \mathrm{y} \\
\text { - } \quad \text { up to } 24 \mathrm{~h}\end{array}$ & $\mathrm{y}$ & $\mathrm{y}$ & $\mathrm{n}$ & $\mathrm{y}$ \\
\hline $\begin{array}{l}\text { Diabetes } \\
\text { Australia }\end{array}$ & $\mathrm{y}$ & $\begin{array}{l}\text { - } \quad \mathrm{y} \\
\text { - } \quad \text { up to } 24 \mathrm{~h}\end{array}$ & $\mathrm{y}$ & $\mathrm{y}$ & $\mathrm{y}$ & $\mathrm{y}$ \\
\hline $\begin{array}{l}\text { Diabetes } \\
\text { New Zealand }\end{array}$ & $\mathrm{y}$ & $\begin{array}{ll}- & \mathrm{n} \\
\text { - } & \mathrm{n} . \mathrm{s}\end{array}$ & $\mathrm{y}$ & $\mathrm{n}$ & $\mathrm{y}$ & $\mathrm{y}$ \\
\hline $\begin{array}{l}\text { Diabetic } \\
\text { Society } \\
\text { Singapore }\end{array}$ & $\mathrm{y}$ & $\begin{array}{ll}- & \mathrm{y} \\
- & \mathrm{n} . \mathrm{s}\end{array}$ & $\mathrm{y}$ & $\mathrm{y}$ & $\mathrm{n}$ & $\mathrm{y}$ \\
\hline Diabetes UK & $\mathrm{y}$ & $\begin{array}{l}\text { - } y \\
\text { - up to } 16 \mathrm{~h} \\
\end{array}$ & $\mathrm{y}$ & $\mathrm{y}$ & $\mathrm{n}$ & $\mathrm{y}$ \\
\hline
\end{tabular}

